Bull. Fac. Agric., Cairo Univ., 70:247-255(2019).

\title{
PHYSIOLOGICAL STUDIES ON GERMINATION AND FERTILIZATION OF SOPHORA PLANT. \\ 1- ENHANCING GERMINATION OF MESCAL BEAN (Sophora secundiflora) SEEDS HARD-TO-GERMINATE.
}

(Received: 17.9.2019)

\author{
By \\ A. W. Sayed \\ Ornamental Plants and Landscape Gardening, Research Department Horticulture Research Institute, \\ Agriculture Research Center, Giza, Egypt.
}

\begin{abstract}
The seeds of Mescal-bean (Sophora secundiflora) have an extremely hard red shells and can take years to germinate. The current study was undertaken to break the physical dormancy of such seeds under semi-shade at the nursery of Al- Zohriya Garden, Hort. Res. Inst., ARC, Giza, Egypt, during 2017 and 2018 seasons by subjecting them to some pre-sowing treatments includeing untreated seeds (control), soaking in tap water for $48 \mathrm{~h}$. at room temperature, soaking in hot water $\left(60-70^{\circ} \mathrm{C}\right)$ for $48 \mathrm{~h}$ (thermal scarification), rasping with a file (mechanical scarification), rasping + soaking in tap water for $24 \mathrm{~h}$. (combined treatment) and soaking in concentrated sulfuric acid $(98.5 \%$ ) for 1, 2 or $3 \mathrm{~h}$. (chemical scarification). The seeds were sown in 16-cm-diameter plastic pots (10 seeds/pot) filled with about 1.5 $\mathrm{kg}$ of an equal mixture of sand and clay $(1: 1, \mathrm{v}: \mathrm{v})$.

The results indicated that the highest germination percentage $(\mathrm{G} \%)$ and the least No. days to either $50 \%$ germination or higher were achieved by soaking in hot water for $48 \mathrm{~h}$ treatment in both seasons, while control and all other treatments failed to increase $\mathrm{G} \%$ to $50 \%$ in both seasons. The best germination rate index, vigour index, seed viability and epicotyl length were also attained by hot water treatment. Soaking the seeds in tap water for $48 \mathrm{~h}$. under room temperature did not affect the amount water uptake by the seeds, while other treatments greatly affected this parameter, as the greatest amount of water was taken up by the seeds rasped with a file or soaked in concen. $\mathrm{H}_{2} \mathrm{SO}_{4}$ for $3 \mathrm{~h}$. treatments followed by soaking the seeds in hot water. However, the former treatments made the seeds absorb the maximum amount of water in the first $24 \mathrm{~h}$., and this amount was steady afterwards, whereas the latter made water absorption continuous till the end of soaking time. A similar response occurred as well in respect of seedling vegetative and root growth measurements and the leaf content of pigments, total soluble sugars and indoles, as hot water treatment gave the utmost high means at all. In addition, the different treatments induced a marked decrement in the concentration of phenols, where the greatest decrement was also recorded by the hot water treatment. From the foregoing, it can be recommended to soak seeds of Mescal-bean (Sophora secundiflora) tree in hot water $\left(60-70^{\circ} \mathrm{C}\right.$ ) for $48 \mathrm{~h}$. to score the best germination and seedling growth.
\end{abstract}

Key words: Mescal-bean (Sophora secundiflora), germination, pre-sowing treatments, scarification treatments .

\section{INTRODUCTION}

Mescal-bean (Sophora secundiflora (Ort.) Lag ex. DC.), or Texas mountain laurel (Fam. Fabaceae) is a small tree with evergreen compound leaves that bear beautiful lavenderamethyst colored clusters of pea-like flowers smelling of "grape koolaid" with bright red seeds in a semi-woody pods Fig. (1). It is native to dry, rocky limestone soils and is droughtresistant after establishment. It makes a beautiful specimen plant in the landscape (Huxley et al., 1992).

Mescal-bean (Sophora secundiflora) is not propagated from cuttings and the seeds have an extremely hard red shell and can take years to germinate after they fall from the tree (Mueller, 2011). However, seeds of most fabaceous species respond well to various pre-sowing treatments, including thermal, mechanical and chemical scarification. In this regard, Ruter and Ingram 


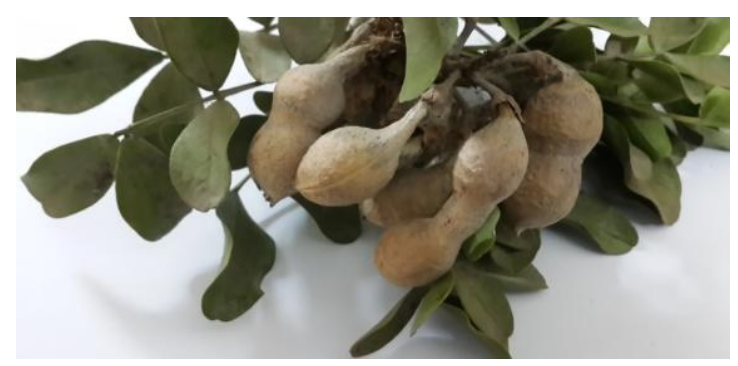

Fig. (1): Leaves and pods of Sophora secundiflora.

(1991) found that the germination rate of $S$. secundiflora increased as acid pretreatment time increased from 30 to 120 minutes. Soaking seeds in water at room temperature or in hot water (93 ${ }^{\circ} \mathrm{C}$ ) for $24 \mathrm{~h}$. had no effect on germination. Wang (1991) revealed that chemical scarification with undiluted $\mathrm{H}_{2} \mathrm{SO}_{4}(93 \%)$ for 10 min. with fresh seeds or for $60 \mathrm{~min}$. with 1year-old seeds enhanced germination to 80 and $70 \%$, respectively and reduced germination time to within 14 days. Mechanical scarification by drilling a small hole through the hard seed coat resulted in relatively quick and the highest rate of germination. Shao et al., (2010) and Aliloo and Mustafavi (2014) reported that immersion in diluted or concentrated $\mathrm{H}_{2} \mathrm{SO}_{4}$ (65 and $98 \%$. respectively) for $30 \mathrm{~min}$. increased Sophora davidii, seed germination and seedling emergence most efficiently. In addition, Delgado et al. (2015) stated that beside the lens, the hilum and micropyle are involved in water absorption in seeds of Sophora tomentosa scarified with hot water.

There were also several reports dealing with seed germination of other ornamental plants such as those reported by Agba et al. (2005) who mentioned that hot water treatment at 40$60^{\circ} \mathrm{C}$ significantly enhanced germination of Mucuna flagellipes seeds compared to hot water treatment at higher temperatures (80 and 100 $\left.{ }^{\circ} \mathrm{C}\right)$. Soaking in water at room temperature for 36-48 h. resulted in higher cumulative germination over planting of seeds without presowing treatment. Kak et al. (2007) postulated that hot water at $80{ }^{\circ} \mathrm{C}$ for $5 \mathrm{~min}$. was most effective in breaking hardseededness in Carotalaria laburnfolia, while germination declined sharply in $C$. retusa when seeds were soaked in water at $70{ }^{\circ} \mathrm{C}$ for $15 \mathrm{~min}$. Soaking $C$. pallida, seeds in hot water at $60{ }^{\circ} \mathrm{C}$ for $30 \mathrm{~min}$. enhanced germination. Likewise, these observations were indicated by Sanyang et al. (2008) on Acacia senegal, Burrows et al. (2009) on
Acacia melanoxylon, Azad et al. (2010) on Albizia richardiana and Lagerstroemia speciosa, Azad et al. (2012) on Albizia procera, Rodrigues Junior et al. (2014) on Senna multijuga, Imani et al. (2014) on Canna indica, Jaganathan et al. (2017) on Delonix regia and Jaganathan et al. (2018) who noticed that Adenanthera pavonina seeds treated with hot water and exposed to summer-autumn temperature regimes broke dormancy and gave the longest radicle .

The aim of the present study was to explore the most suitable pre-sowing treatment reliable to break the hardseededness of Mescalbean sophora seeds.

\section{MATERIALS AND METHODS}

The current work was conducted under semishade at the nursery of Al- Zohriya Garden, Hort. Res. Inst., ARC, Giza, Egypt, throughout the two successive seasons of 2017 and 2018 in order to overcome the physical dormancy of Mescal-bean sophora seeds due to their extremely hard red shells.

Thus,1-year-old semi-woody pods of Mescalbean (Sophora secundiflora) were collected from a strong mature tree in Al- Zohriya Garden, Cairo on August, $12^{\text {th }}$ for each season. The seeds were removed from the tough pods using a sharp knife, as they were shrinked and had deep red outer coats (the mean weight of 5 seeds was about $3.52 \mathrm{~g}$, while diameter of the seed ranged between 10.50-13.35 mm) (Fig.2).

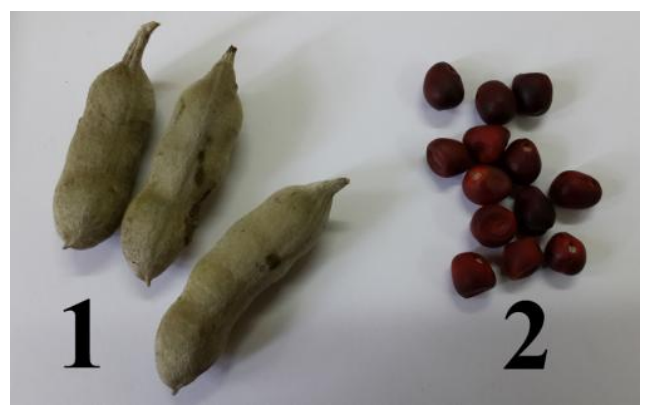

Fig. (2): Semi-woody pods (1) and seeds with hard red shell (2).

On August, $15^{\text {th }}$, the outer coats of the seeds were sterilized with $10 \%$ of sodium hydrochloride solution for 10 minutes, then rinsed several times with sterile distillated water and directly subjected to the following presowing treatments.

1. Untreated seeds, referred to as control.

2. Soaking in tap water for 48 hours at ambient conditions. 
3. Soaking in hot water $\left(60-70{ }^{\circ} \mathrm{C}\right)$ for 48 hours (as thermal scarification).

4. Rasping with a file (RWF) as the seeds were hold with a pliers and with a file rub one spot of the outer coat (at the larger cotyledon end) until the thin light-coloured inner coat is visible (as mechanical scarification treatment) .

5. Mechanical scarification (RWF) + soaking in tap water for 24 hours (as combined treatment).

6. Soaking in concentrated sulfuric acid (98.5\%) for 1, 2 or 3 hours (as chemical scarification treatments).

Immediately after treatment, the treated seeds and those of the control were sown in $16-\mathrm{cm}$ diameter plastic pots (10 seeds/ pot) filled with about $1.5 \mathrm{~kg}$ of sand and clay mixture at equal parts by volume $(1: 1, \mathrm{v} / \mathrm{v})$. The physical and chemical properties of the sand and clay used in the two seasons are shown in Table (1).
2- Germination velocity (G.V.) in days, which equal average number of days from sowing till emergence of the last epicotyl .

3- Mean germination rate (M.G.R.) in days = mean No. days till $50 \%$ germination (Odetola, 1987).

4- Germination rate index (G.R.I.), which was calculated from Bartled equation indicated by Hartmann and Kester (1983). GRI = A + (A $+\mathrm{B})+(\mathrm{A}+\mathrm{B}+\mathrm{C})+\ldots / \mathrm{N}(\mathrm{A}+\mathrm{B}+\mathrm{C} \ldots$.$) .$

Where: $\mathrm{A}, \mathrm{B}, \mathrm{C}, \ldots$ etc. are number of germinated seeds counted at different times, and $\mathrm{N}$ is number of times at which the germinated seeds were counted.

5- Vigour index (V.I.) $=\mathrm{G} \% \mathrm{x}$ mean length of epicotyl (Selvaraju and Selvaraj, 1994)

6- Seed viability (S.V.) = No. survived seedlings in each treatment after excluding the deteriorated and dead ones (Odetola, 1987).

Besides, the amount of water imbibed by treated seeds (g) were determined by fresh

Table (1):The physical and chemical analysis of the used sand and clay during 2017 and 2018 seasons.

\begin{tabular}{|c|c|c|c|c|c|c|c|c|c|c|c|c|c|c|c|}
\hline \multirow[b]{2}{*}{$\begin{array}{l}\text { Soil } \\
\text { type }\end{array}$} & \multirow[b]{2}{*}{ Seasons } & \multicolumn{4}{|c|}{ Particle size distribution (\%): } & \multirow[b]{2}{*}{ S.P. } & \multirow[b]{2}{*}{ pH } & \multirow{2}{*}{$\begin{array}{l}\text { E.C. } \\
\text { (dS } \\
/ \mathbf{m})\end{array}$} & \multicolumn{4}{|c|}{ Cations (meq /l) } & \multicolumn{3}{|c|}{ Anions (meq/l) } \\
\hline & & $\begin{array}{c}\text { Coarse } \\
\text { sand }\end{array}$ & $\begin{array}{l}\text { Fine } \\
\text { sand }\end{array}$ & Silt & Clay & & & & $\mathrm{Ca}^{++}$ & $\mathbf{M g}^{++}$ & $\mathbf{N a}^{+}$ & $\mathbf{K}^{+}$ & $\mathrm{HCO}_{3}{ }^{-}$ & $\mathrm{Cl}^{-}$ & $\mathrm{SO}_{4}^{--}$ \\
\hline \multirow{2}{*}{ Sand } & 2017 & 89.03 & 2.05 & 0.40 & 8.52 & 23.00 & 7.92 & 3.72 & 7.50 & 1.63 & 33.60 & 0.50 & 3.20 & 22.00 & 18.03 \\
\hline & 2018 & 90.10 & 1.95 & 0.50 & 7.45 & 22.86 & 7.89 & 3.70 & 19.42 & 8.33 & 7.20 & 0.75 & 1.60 & 7.00 & 27.10 \\
\hline \multirow{2}{*}{ Clay } & 2017 & 7.54 & 22.28 & 30.55 & 39.63 & 55.00 & 8.17 & 2.26 & 7.82 & 2.12 & 15.40 & 0.75 & 6.60 & 8.20 & 11.29 \\
\hline & 2018 & 7.64 & 22.50 & 30.15 & 39.71 & 51.00 & 8.09 & 2.38 & 7.50 & 2.20 & 15.50 & 0.75 & 6.78 & 8.02 & 11.15 \\
\hline
\end{tabular}

The layout of the experiment in both seasons was a completely randomized design, replicated thrice as each pot contained 10 seeds exemplifies one replicate (Mead et al., 1993). Clearly visible a protrusion of slender shoot (epicotyl) with the beginnings of the first true leaves was used as the first sign of germination (Ruter and Ingram, 1991). All agricultural practices required for care the seeds were carried out in time. Number of germinated seeds was counted daily and length of epicotyl $(\mathrm{cm})$ was measured after a week from emergence to calculate germination traits as follows:

1- Germination percentage $(\mathrm{G} \%)$ from the following equation:

G. $\%=$ No. germinated seeds/ Total No. sown seeds x 100 weight increase among 3 replications of 3 seeds each, as seeds were immersed in tap water under ambient temperature $\left(35-36{ }^{\circ} \mathrm{C}\right)$ and weighed every 12 h. for 60 h. (i.e. 5 times). Excess water was removed with filter paper before weighing. Result were expressed as water amount (g) uptook by seeds through the different times of immersing calculated by subtracting seed weight before soaking from seed weight after soaking ( Brasil,1992) .

At the end of each season (on October, $15^{\text {th }}$ ), data of the resulted seedlings from the different treatments were recorded as follows: seedling length $(\mathrm{cm})$, number of leaves/seedling, root length $(\mathrm{cm})$, number of roots/seedling as well as fresh and dry weights of top growth and roots (g). 
In fresh leaf samples taken only in the second season, photosynthetic pigments (chlorophyll a, $\mathrm{b}$ and carotenoids, $\mathrm{mg} / \mathrm{g} \mathrm{f}$. w.) were determined according to the method of Moran (1982). The percentage of total soluble sugars, and total indoles and total phenols $(\mathrm{mg} / 100 \mathrm{~g} \mathrm{f}$. w.) were also evaluated by the methods described by Dubois et al. (1956), A.O.A.C (1990) and William et al. (1965), respectively.

Data were then tabulated and statistically analyzed according to program of SAS Institute (2009), followed by Duncan's New Multiple Range Test (Steel and Torrie,1980) for comparison among means.

\section{RESULTS AND DISCUSSION}

\subsection{Effect of pre-sowing treatments on}

\subsubsection{Germination traits and epicotyl length}

Data in Table (2) exhibit that germination \% reached to the maximum value $(65.76 \%$ in the first season and $72.33 \%$ in the second) by soaking in hot water for $48 \mathrm{~h}$., while other treatments including the control recorded germination percentage ranged between 12.50 and $33.33 \%$ in the $1^{\text {st }}$ season and 12.50 to $25 \%$ in the $2^{\text {nd }}$ season with non-significant differences among themselves in most cases of both seasons. However, the least percentage of germination $(12.50 \%)$ was achieved in both seasons by the control and rasping with a file treatments. This may indicate the role of hot water in softening the hard seed coat from all sides and cracking it in more than one position. In this concern, Hu et al. (2008) found that seed coats of Sophora alopecuroides seeds cracked in the hilum when pre-treated with sulfuric acid and after field exposure, but they cracked in both the hilum and extrahilar regions when treated with hot water, thus causing seeds to enter a fast imbibition stage. This finding was documented by Delgado et al. (2015) who mentioned that beside the lens, the hilum and micropyle are involved in water absorption in seeds of Sophora tomentosa scarified with hot water.

Moreover, the least number of days to either the highest percentage of germination velocity (G.V.) or to $50 \%$ mean germination rate (M.G.R.) were also attained by hot water treatment that raised $\mathrm{G} \%$ to $50 \%$ in about 13.75 day and to $65.76 \%$ in about 16.6 day in the first season, while in the second one these two parameters were scored after about 14.00 and 15.87 day from sowing the seeds, respectively. All the other treatments failed to elevate $\mathrm{G} \%$ to $50 \%$ in the two seasons. The best results of germination rate index (G.R.I.), as a real indicator for accelerating germination was also registered by hot water treatment that reduced

Table (2): Effect of pre-germination treatments on germination characteristics of Sophora secundiflora seeds during 2017and 2018 seasons.

\begin{tabular}{|c|c|c|c|c|c|c|c|}
\hline Treatments & $\begin{array}{c}\text { Germination } \\
(\%)\end{array}$ & $\begin{array}{c}\text { Germination } \\
\text { velocity } \\
\text { (day) }\end{array}$ & \begin{tabular}{|c|} 
Mean \\
germination \\
rate (day) \\
\end{tabular} & $\begin{array}{c}\text { Germination } \\
\text { rate index }\end{array}$ & \begin{tabular}{|l|} 
Vigour \\
index
\end{tabular} & \begin{tabular}{|c|} 
Seed \\
viability
\end{tabular} & $\begin{array}{c}\text { Epicotyl } \\
\text { length } \\
\text { (cm) } \\
\end{array}$ \\
\hline & \multicolumn{7}{|c|}{$\begin{array}{ll} & \text { First season: } 2017 \\
\end{array}$} \\
\hline Control & $12.50 \mathrm{c}$ & $36.10 \mathrm{a}$ & $0.00 \mathrm{~b}$ & $1.00 \mathrm{a}$ & $16.25 \mathrm{~d}$ & $3.00 \mathrm{c}$ & $1.30 \mathrm{c}$ \\
\hline Soaking in T.W. for $48 \mathrm{~h}$. & $25.00 \mathrm{bc}$ & $26.76 b$ & $0.00 \mathrm{~b}$ & $1.00 \mathrm{a}$ & $33.25 \mathrm{~cd}$ & $6.00 \mathrm{~b}$ & $1.33 \mathrm{c}$ \\
\hline Soaking in H.W. for $48 \mathrm{~h}$. & $65.76 \mathrm{a}$ & $16.60 \mathrm{~d}$ & $13.75 \mathrm{a}$ & $0.60 \mathrm{c}$ & $131.52 \mathrm{a}$ & $15.67 \mathrm{a}$ & $2.00 \mathrm{a}$ \\
\hline Rasping with a file (R.W.F.) & $2.50 \mathrm{c}$ & $30.00 \mathrm{ab}$ & $0.00 \mathrm{~b}$ & $1.00 \mathrm{a}$ & $16.63 \mathrm{~d}$ & $3.33 \mathrm{c}$ & $1.33 \mathrm{c}$ \\
\hline RWF + soaking in T.W. for $24 \mathrm{~h}$. & $3.33 b$ & $26.33 b$ & $0.00 \mathrm{~b}$ & $1.00 \mathrm{a}$ & $47.33 \mathrm{~b}$ & $3.76 \mathrm{c}$ & $1.42 \mathrm{bc}$ \\
\hline Soaking in CSA for $1 \mathrm{~h}$. & $25.00 \mathrm{bc}$ & $19.50 \mathrm{c}$ & $0.00 \mathrm{~b}$ & $0.75 b$ & $37.50 \mathrm{c}$ & $6.00 \mathrm{~b}$ & $1.50 \mathrm{~b}$ \\
\hline Soaking in CSA for $2 \mathrm{~h}$. & $25.00 \mathrm{bc}$ & $19.50 \mathrm{c}$ & $0.00 \mathrm{~b}$ & $1.00 \mathrm{a}$ & $37.50 \mathrm{c}$ & $6.00 \mathrm{~b}$ & $1.50 \mathrm{~b}$ \\
\hline \multirow[t]{2}{*}{ Soaking in CSA for $3 \mathrm{~h}$. } & $25.00 \mathrm{bc}$ & $19.00 \mathrm{c}$ & $0.00 \mathrm{~b}$ & $0.75 b$ & $37.50 \mathrm{c}$ & $6.00 \mathrm{~b}$ & $1.50 \mathrm{~b}$ \\
\hline & \multicolumn{7}{|c|}{ Second season: 2018} \\
\hline Control & $2.50 \mathrm{~b}$ & $35.33 \mathrm{a}$ & $0.00 \mathrm{~b}$ & $1.00 \mathrm{a}$ & $15.38 \mathrm{c}$ & $3.00 \mathrm{c}$ & $1.23 \mathrm{c}$ \\
\hline Soaking in T.W. for $48 \mathrm{~h}$. & $25.00 \mathrm{~b}$ & $27.00 \mathrm{bc}$ & $0.00 \mathrm{~b}$ & $1.00 \mathrm{a}$ & $32.50 \mathrm{~b}$ & $6.00 \mathrm{~b}$ & $1.30 \mathrm{bc}$ \\
\hline Soaking in H.W. for $48 \mathrm{~h}$. & $72.33 \mathrm{a}$ & $15.87 \mathrm{~d}$ & $14.00 \mathrm{a}$ & $0.56 \mathrm{c}$ & $151.89 \mathrm{a}$ & $15.00 \mathrm{a}$ & $2.10 \mathrm{a}$ \\
\hline Rasping with a file (R.W.F.) & $12.50 \mathrm{~b}$ & $30.33 b$ & $0.00 \mathrm{~b}$ & $1.00 \mathrm{a}$ & $15.88 \mathrm{c}$ & $3.00 \mathrm{c}$ & $1.27 \mathrm{c}$ \\
\hline RWF + soaking in T.W. for $24 \mathrm{~h}$. & $25.00 \mathrm{~b}$ & $25.76 \mathrm{bc}$ & $0.00 \mathrm{~b}$ & $1.00 \mathrm{a}$ & $33.50 \mathrm{~b}$ & $3.00 \mathrm{c}$ & $1.34 \mathrm{bc}$ \\
\hline Soaking in CSA for $1 \mathrm{~h}$. & $25.00 \mathrm{~b}$ & $21.50 \mathrm{c}$ & $0.00 \mathrm{~b}$ & $1.00 \mathrm{a}$ & $35.00 \mathrm{~b}$ & $6.00 \mathrm{~b}$ & $1.40 \mathrm{~b}$ \\
\hline Soaking in CSA for $2 \mathrm{~h}$. & $25.00 \mathrm{~b}$ & $21.33 \mathrm{c}$ & $0.00 \mathrm{~b}$ & $0.75 b$ & $35.00 \mathrm{~b}$ & $6.00 \mathrm{~b}$ & $1.40 \mathrm{~b}$ \\
\hline Soaking in CSA for $3 \mathrm{~h}$. & $25.00 \mathrm{~b}$ & $21.33 \mathrm{c}$ & $0.00 \mathrm{~b}$ & $0.75 b$ & $36.00 \mathrm{~b}$ & $6.33 b$ & $1.44 \mathrm{~b}$ \\
\hline
\end{tabular}

-T.W.= Tap water,H.W.= Hot water,CSA= Concentrated sulfuric acid .

- Means within a column having the same letters are not significantly different according to Duncan's New Multiple Range t-Test (DMRT) at $5 \%$ level. 
such parameter to 0.60 and 0.56 against 0.75 or 1.00 for other treatments in the first and second seasons, respectively. Similarly, were those results of vigour index, seed viability and epicotyl length $(\mathrm{cm})$ traits, which also reached the maximum values by hot water treatment in the two seasons.

This may be ascribed to the role of hot water in reducing the hardseededness of the seed shell and cracking it to a level that permits the fast permeable of water and oxygen which activates enzymes to decay food reserve, producing sugars and energy required for embryo growth. These gains are in agreement with those revealed by Delgedo et al. (2015) on Sophora tomentosa, Agba et al. (2005) on Mucuna flagellipes, Kak et al. (2007) on Carotalaria laburnfolia and $C$. pallida, Burrows et al. (2009) on Acacia melanoxylon Rodrigues Junior et al. (2014) on Senna multijuga, Jaganathan et al. (2017) on Delonix regia and Jaganathan et al. (2018) on Adenanthera pavonina .

\subsection{Water imbibition}

It can be seen from the data in Table (3) that there was not any variable in fresh weight of seeds during the different stages of soaking in tap water under room temperature up to $60 \mathrm{~h}$. So, germination $\%$ was the minimum and the seeds took the longest period to germinate in both seasons. The opposite was time regarding the other treatments, as the greatest water amount taken by the seeds rasped with a file or soaked in concentrated $\mathrm{H}_{2} \mathrm{SO}_{4}$ for $3 \mathrm{~h}$. and directly followed by those soaked in the acid for 1 or $2 \mathrm{~h}$. However, in these treatments, seeds absorbed the greatest amount of water in the first $24 \mathrm{~h}$., while after that water absorption was to some extent stable or slightly reduced with elongating soaking periods. On the other hand, seeds soaked in hot water still absorb water till the end of soaking period. This means that the hard seed shell becomes more soften by hot water, so imbibition and seed swelling still occur, while coats of the seeds rasped with a file or soaked in acid did not soften enough, therefore the former treatment (hot water) recorded better germination characteristics than the latter ones (mechanical or acid scarification).

The results are supported by those indicated by $\mathrm{Hu}$ et al. (2008) on Sophora alopecuroides, Delgado et al. (2015) on Sophora tomentosa, Azad et al. (2010) on Albizia richardiana and Lagerstroemia speciosa and Azad et al. (2012) on Albizia procera.

\subsection{Seedling growth traits}

According to the data presented in Tables (4 and 5), it could be concluded that all pre-sowing treatments used in this work significantly improved length $(\mathrm{cm})$, No. leaves and roots/seedling, root length $(\mathrm{cm})$, as well as top growth and roots fresh and dry weights of the seedlings resulted from the treated seeds comparing with those of the control seedlings in the two seasons, except of rasping with a file treatment, alone or plus soaking in tap water for $24 \mathrm{~h}$. that non-significantly improved length, No leaves and fresh and dry weights of top growth and roots parameters relative to control in most cases of both seasons. In addition, the differences among the various applied treatments concerning fresh and dry weights of top growth and roots were not significant in most instances of both seasons. However, the prevalence in all abovenamed characters was found due to hot water treatment which recorded the utmost high growth rates over the control and all other treatments in the two seasons (Fig.3).

Table (3): Effect of pre-germination treatments on water imbibition by Sophora secundiflora seeds after different periods from soaking in tap water under ambient conditions.

\begin{tabular}{|c|c|c|c|c|c|c|c|c|c|c|c|}
\hline \multirow{3}{*}{$\begin{array}{c}\text { Pre-germination } \\
\text { treatments }\end{array}$} & \multirow{3}{*}{$\begin{array}{c}\text { Seed } \\
\text { weight } \\
\text { before } \\
\text { soaking } \\
\text { (g) }\end{array}$} & \multicolumn{10}{|c|}{ Seed weight and water amount imbibed (g) } \\
\hline & & \multicolumn{2}{|c|}{ After $12 \mathrm{~h}$. } & \multicolumn{2}{|c|}{ After 24 h. } & \multicolumn{2}{|c|}{ After 36 h. } & \multicolumn{2}{|c|}{ After $48 \mathrm{~h}$. } & \multicolumn{2}{|c|}{ After 60 h. } \\
\hline & & $\begin{array}{c}\text { Seed } \\
\text { weight }\end{array}$ & $\begin{array}{c}\text { Water } \\
\text { amount }\end{array}$ & \begin{tabular}{|c|} 
Seed \\
weight
\end{tabular} & $\begin{array}{l}\text { Water } \\
\text { amount }\end{array}$ & \begin{tabular}{|c|} 
Seed \\
weight
\end{tabular} & $\begin{array}{l}\text { Water } \\
\text { amount }\end{array}$ & \begin{tabular}{|c|} 
Seed \\
weight
\end{tabular} & $\begin{array}{l}\text { Water } \\
\text { amount }\end{array}$ & \begin{tabular}{|c|} 
Seed \\
weight
\end{tabular} & $\begin{array}{l}\text { Water } \\
\text { tamount }\end{array}$ \\
\hline Soaking in T.W. & 0.54 & $0.56 \mathrm{c}$ & $0.02 \mathrm{~d}$ & $0.56 \mathrm{c}$ & $2 \mathrm{c}$ & $0.56 \mathrm{c}$ & $0.02 c$ & $0.56 \mathrm{c}$ & $0.02 c$ & $0.56 \mathrm{c}$ & $0.02 c$ \\
\hline Soaking in H.W. & 0.59 & $0.77 \mathrm{bc}$ & $0.18 \mathrm{c}$ & $1.05 \mathrm{~b}$ & & $1.10 \mathrm{~b}$ & $0.51 \mathrm{~b}$ & $1.12 \mathrm{ab}$ & $0.53 \mathrm{ab}$ & $1.14 \mathrm{ab}$ & $0.55 \mathrm{ab}$ \\
\hline Rasping with a file & 0.57 & $0.79 \mathrm{bc}$ & $0.22 \mathrm{c}$ & $1.28 \mathrm{ab}$ & $71 \mathrm{a}$ & $1.29 \mathrm{a}$ & $0.72 \mathrm{a}$ & $1.28 \mathrm{a}$ & $0.71 \mathrm{a}$ & $1.26 \mathrm{a}$ & $0.69 \mathrm{a}$ \\
\hline Soaking in CSA for $1 \mathrm{~h}$. & 0.46 & $0.89 \mathrm{~b}$ & $0.43 b$ & $0.92 b$ & $0.46 \mathrm{~b}$ & $0.96 \mathrm{~b}$ & $0.50 \mathrm{~b}$ & $0.96 \mathrm{~b}$ & $0.50 \mathrm{ab}$ & $0.95 b$ & $0.49 \mathrm{~b}$ \\
\hline Soaking in CSA for $2 \mathrm{~h}$. & 0.50 & $0.90 \mathrm{~b}$ & $0.40 \mathrm{~b}$ & $0.92 b$ & $0.42 \mathrm{~b}$ & $0.95 b$ & $0.45 b$ & $0.96 \mathrm{~b}$ & $0.46 \mathrm{~b}$ & $0.97 \mathrm{~b}$ & $0.47 \mathrm{~b}$ \\
\hline Soaking in CSA for $3 \mathrm{~h}$. & 0.61 & $1.35 \mathrm{a}$ & $0.74 a$ & $1.40 \mathrm{a}$ & $0.79 a$ & $1.39 \mathrm{a}$ & $0.78 \mathrm{a}$ & $1.38 \mathrm{a}$ & $0.77 \mathrm{a}$ & $1.33 \mathrm{a}$ & $0.72 \mathrm{a}$ \\
\hline
\end{tabular}

- T.W. = Tap water, H.W. = Hot water and CSA = Concentrated sulfuric acid.

- Means within a column having the same letters are not significantly different according to Duncan's New

Multiple Range t-Test (DMRT) at $5 \%$ level. 


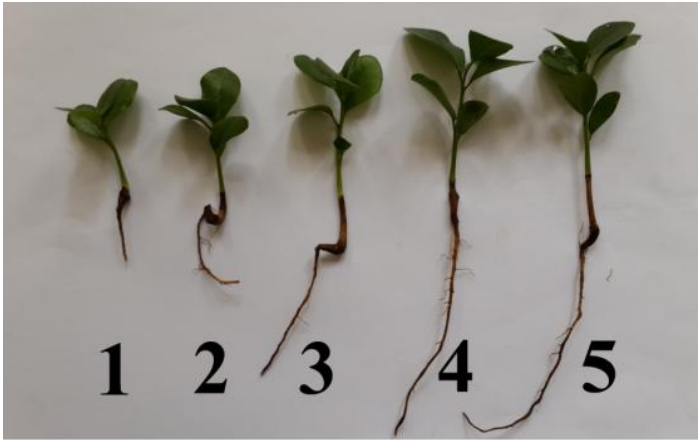

Fig. (3): Seedling produced from control (1), rasping treatment (2), soaking in acid for either 2h.(3),or 3h.(4) and soaking in hot water (5).

This may be reasonable because hot water treatment is the most one that accelerates germination velocity, so saving time for the seedlings to grow better than those resulted from other treatments. Analogous observations were also noticed by Kak et al. (2007) on Carotalaria laburnfolia and C. pallida, Sanyang et al. (2008) on Acacia senegal and Burrows et al. (2009) on Acacia melanoxylon. In this connection, Azad et al. (2012) stated that hot water at $100{ }^{\circ} \mathrm{C}$ for 1 min. gave highly quality of Albizia procera seedlings.

\subsection{Chemical composition of the leaves}

It is clear from data averaged in Table (6) that chlorophyll a and carotenoids concentrations ( $\mathrm{mg} / \mathrm{g} \mathrm{f}$. w.) were significantly increased in the leaves of seedlings raised from treated seeds with the superiority of hot water treatment that resulted the highest values of these two pigments and followed by acid treatment for any time, then soaking in tap water for $48 \mathrm{~h}$. and rasping with a file treatments, which occupied the $3^{\text {rd }}$ position as they caused the least improvement. In the matter of chlorophyll $b$ concentration, the opposite was the right as it was non-significantly declined in response to the various used treatments except of acid treatment for $3 \mathrm{~h}$. which slightly elevated such component to 0.210 $\mathrm{mg} / \mathrm{g} \mathrm{f}$. w. and hot water treatment for $48 \mathrm{~h}$ which significantly increased it to $0.311 \mathrm{mg} / \mathrm{g} \mathrm{f}$. w. versus $0.201 \mathrm{mg} / \mathrm{g}$. f. w. for control.

A significant increment was also observed in the percentage of total soluble sugars and total indoles (mg/100 g f. w.) due to the pre-sowing treatments employed in this study compared to the control, except treatments of soaking in tap water (48 h.), rasping with a file and soaking in acid for $1 \mathrm{~h}$. that caused a slight increase, but the mastery was also for hot water treatment which gave the utmost high means. On the other side, a marked decrement was attained concerning the total phenols concentration by the various used treatments with mostly significant differences relative to the control. However, the greatest decrement in such constituent was scored by hot water treatment which diminished it to 0.789 against $2.187 \mathrm{mg} / 100 \mathrm{~g} \mathrm{f}$. w. for the control. Thus, the best equilibrium between indoles and phenols suitable for enhancing germination and seedling growth was achieved by hot water treatment that raised indoles level to the maximum value plus decreasing phenols content to the minimum.

Table (4): Effect of pre-germination treatments on growth parameters of Sophora secundiflora seedlings during 2017 and 2018 seasons.

\begin{tabular}{|l|c|c|c|c|c|c|c|c|}
\hline \multirow{2}{*}{ Treatments } & \multicolumn{2}{|c|}{$\begin{array}{c}\text { Seedling } \\
\text { length }(\mathbf{c m})\end{array}$} & \multicolumn{2}{|c|}{$\begin{array}{c}\text { No. leaves } \\
\text { /seedling }\end{array}$} & \multicolumn{2}{|c|}{$\begin{array}{c}\text { Root length } \\
\text { (cm) }\end{array}$} & \multicolumn{2}{|c|}{$\begin{array}{c}\text { No. roots/ } \\
\text { Seedling }\end{array}$} \\
\cline { 2 - 8 } & $\mathbf{2 0 1 7}$ & $\mathbf{2 0 1 8}$ & $\mathbf{2 0 1 7}$ & $\mathbf{2 0 1 8}$ & $\mathbf{2 0 1 7}$ & $\mathbf{2 0 1 8}$ & $\mathbf{2 0 1 7}$ & $\mathbf{2 0 1 8}$ \\
\hline Control & $2.80 \mathrm{c}$ & $2.93 \mathrm{c}$ & $3.33 \mathrm{c}$ & $4.00 \mathrm{c}$ & $3.10 \mathrm{~d}$ & $4.26 \mathrm{~d}$ & $2.33 \mathrm{e}$ & $3.00 \mathrm{e}$ \\
\hline Soaking in T.W. for 48 h. & $4.43 \mathrm{~b}$ & $4.60 \mathrm{ab}$ & $5.00 \mathrm{~b}$ & $5.00 \mathrm{~b}$ & $7.33 \mathrm{bc}$ & $8.00 \mathrm{~b}$ & $4.51 \mathrm{~d}$ & $5.63 \mathrm{bc}$ \\
\hline Soaking in H.W. for 48 h. & $5.67 \mathrm{a}$ & $5.38 \mathrm{a}$ & $6.10 \mathrm{a}$ & $6.50 \mathrm{a}$ & $12.70 \mathrm{a}$ & $10.83 \mathrm{a}$ & $8.55 \mathrm{a}$ & $7.68 \mathrm{a}$ \\
\hline Rasping with a file (R.W.F.) & $4.00 \mathrm{bc}$ & $3.51 \mathrm{c}$ & $4.00 \mathrm{c}$ & $4.00 \mathrm{c}$ & $6.17 \mathrm{c}$ & $6.00 \mathrm{c}$ & $4.70 \mathrm{~d}$ & $4.25 \mathrm{~d}$ \\
\hline RWF + soaking in T.W. for 24 h. & $4.16 \mathrm{bc}$ & $4.39 \mathrm{ab}$ & $4.10 \mathrm{bc}$ & $4.23 \mathrm{bc}$ & $7.00 \mathrm{c}$ & $7.46 \mathrm{bc}$ & $5.26 \mathrm{c}$ & $5.30 \mathrm{c}$ \\
\hline Soaking in CSA for 1 h. & $4.50 \mathrm{~b}$ & $4.36 \mathrm{~b}$ & $5.00 \mathrm{~b}$ & $5.00 \mathrm{~b}$ & $8.00 \mathrm{~b}$ & $7.91 \mathrm{bc}$ & $6.00 \mathrm{~b}$ & $5.56 \mathrm{c}$ \\
\hline Soaking in CSA for 2 h. & $4.46 \mathrm{~b}$ & $4.50 \mathrm{ab}$ & $5.00 \mathrm{~b}$ & $5.00 \mathrm{~b}$ & $7.63 \mathrm{bc}$ & $8.00 \mathrm{~b}$ & $5.76 \mathrm{bc}$ & $5.61 \mathrm{bc}$ \\
\hline Soaking in CSA for 3 h. & $4.50 \mathrm{~b}$ & $4.67 \mathrm{ab}$ & $5.00 \mathrm{~b}$ & $5.00 \mathrm{~b}$ & $8.50 \mathrm{~b}$ & $9.40 \mathrm{ab}$ & $6.40 \mathrm{~b}$ & $6.62 \mathrm{~b}$ \\
\hline
\end{tabular}

- T.W. = Tap water, H.W. = Hot water and CSA = Concentrated sulfuric acid.

- Means within a column having the same letters are not significantly different according to Duncan's New

Multiple Range t-Test (DMRT) at $5 \%$ level. 
Table (5): Effect of pre-germination treatments on top growth and roots fresh and dry weights of Sophora secundiflora seedlings during 2017 and 2018 seasons.

\begin{tabular}{|l|c|c|c|c|c|c|c|c|}
\hline \multirow{2}{*}{\multicolumn{1}{c|}{ Treatments }} & \multicolumn{3}{|c|}{ Fresh weight (g) } & \multicolumn{4}{c|}{ Dry weight (g) } \\
\cline { 2 - 8 } & Top growth & \multicolumn{2}{c|}{ Roots } & \multicolumn{2}{c|}{ Top growth } & \multicolumn{2}{c|}{ Roots } \\
\cline { 2 - 8 } & $\mathbf{2 0 1 7}$ & $\mathbf{2 0 1 8}$ & $\mathbf{2 0 1 7}$ & $\mathbf{2 0 1 8}$ & $\mathbf{2 0 1 7}$ & $\mathbf{2 0 1 8}$ & $\mathbf{2 0 1 7}$ & $\mathbf{2 0 1 8}$ \\
\hline Control & $0.26 \mathrm{c}$ & $0.32 \mathrm{~b}$ & $0.10 \mathrm{c}$ & $0.12 \mathrm{~b}$ & $0.05 \mathrm{c}$ & $0.06 \mathrm{c}$ & $0.02 \mathrm{c}$ & $0.03 \mathrm{c}$ \\
\hline Soaking in T.W. for 48 h. & $0.41 \mathrm{ab}$ & $0.46 \mathrm{a}$ & $0.14 \mathrm{~b}$ & $0.15 \mathrm{ab}$ & $0.12 \mathrm{~b}$ & $0.14 \mathrm{~b}$ & $0.09 \mathrm{~b}$ & $0.10 \mathrm{ab}$ \\
\hline Soaking in H.W. for 48 h. & $0.58 \mathrm{a}$ & $0.50 \mathrm{a}$ & $0.23 \mathrm{a}$ & $0.21 \mathrm{a}$ & $0.21 \mathrm{a}$ & $0.19 \mathrm{a}$ & $0.15 \mathrm{a}$ & $0.13 \mathrm{a}$ \\
\hline Rasping with a file (R.W.F.) & $0.35 \mathrm{~b}$ & $0.34 \mathrm{~b}$ & $0.12 \mathrm{bc}$ & $0.12 \mathrm{~b}$ & $0.10 \mathrm{~b}$ & $0.10 \mathrm{bc}$ & $0.05 \mathrm{bc}$ & $0.06 \mathrm{bc}$ \\
\hline RWF + soaking in T.W. for 24 h. & $0.38 \mathrm{~b}$ & $0.40 \mathrm{ab}$ & $0.14 \mathrm{~b}$ & $0.14 \mathrm{ab}$ & $0.11 \mathrm{~b}$ & $0.12 \mathrm{~b}$ & $0.08 \mathrm{~b}$ & $0.08 \mathrm{~b}$ \\
\hline Soaking in CSA for 1 h. & $0.42 \mathrm{ab}$ & $0.46 \mathrm{a}$ & $0.16 \mathrm{ab}$ & $0.17 \mathrm{ab}$ & $0.18 \mathrm{ab}$ & $0.20 \mathrm{a}$ & $0.10 \mathrm{ab}$ & $0.11 \mathrm{ab}$ \\
\hline Soaking in CSA for 2 h. & $0.46 \mathrm{ab}$ & $0.47 \mathrm{a}$ & $0.17 \mathrm{ab}$ & $0.17 \mathrm{ab}$ & $0.19 \mathrm{ab}$ & $0.20 \mathrm{a}$ & $0.11 \mathrm{ab}$ & $0.11 \mathrm{ab}$ \\
\hline Soaking in CSA for 3 h. & $0.39 \mathrm{~b}$ & $0.45 \mathrm{a}$ & $0.14 \mathrm{~b}$ & $0.16 \mathrm{ab}$ & $0.11 \mathrm{~b}$ & $0.13 \mathrm{~b}$ & $0.08 \mathrm{~b}$ & $0.09 \mathrm{~b}$ \\
\hline
\end{tabular}

- T.W. = Tap water, H.W. = Hot water and CSA = Concentrated sulfuric acid .

- Means within a column having the same letters are not significantly different according to Duncan's New

Multiple Range t-Test (DMRT) at $5 \%$ level.

Table (6): Effect of pregermination treatments on some constituents in the leaves of Sophora secundiflora seedlings during 2018 season .

\begin{tabular}{|c|c|c|c|c|c|c|}
\hline \multirow[b]{2}{*}{ Treatments } & \multicolumn{3}{|c|}{ Pigments (mg/g f.w.) } & \multirow{2}{*}{\begin{tabular}{|c|} 
Total \\
soluble \\
sugars \\
$(\%)$
\end{tabular}} & \multirow{2}{*}{$\begin{array}{c}\text { Total } \\
\text { indoles } \\
\text { (mg/100 } \\
\text { g.f.w.) }\end{array}$} & \multirow{2}{*}{\begin{tabular}{|c} 
Total \\
phenols \\
(mg/100 \\
g.f.w.)
\end{tabular}} \\
\hline & $\begin{array}{c}\text { Chlorophyll } \\
\mathbf{a}\end{array}$ & $\begin{array}{c}\text { Chlorophyll } \\
\text { b }\end{array}$ & Carotenoids & & & \\
\hline Control & $0.508 \mathrm{~d}$ & $0.201 \mathrm{~b}$ & $0.227 \mathrm{~d}$ & $0.742 \mathrm{~d}$ & $0.612 \mathrm{~d}$ & $2.187 \mathrm{a}$ \\
\hline Soaking in T.W. for $48 \mathrm{~h}$. & $0.693 \mathrm{c}$ & $0.176 \mathrm{c}$ & $0.322 \mathrm{c}$ & $0.769 \mathrm{~d}$ & $1.770 \mathrm{c}$ & $1.379 \mathrm{~b}$ \\
\hline Soaking in H.W. for $48 \mathrm{~h}$. & $0.989 \mathrm{a}$ & $0.311 \mathrm{a}$ & $0.491 \mathrm{a}$ & $1.476 \mathrm{a}$ & $2.779 \mathrm{a}$ & $0.789 \mathrm{~d}$ \\
\hline Rasping with a file (R.W.F.) & $0.701 \mathrm{c}$ & $0.168 \mathrm{c}$ & $0.347 \mathrm{bc}$ & $0.778 \mathrm{~cd}$ & $1.741 \mathrm{c}$ & $2.137 \mathrm{a}$ \\
\hline RWF + soaking in T.W. for $24 \mathrm{~h}$. & $0.716 \mathrm{bc}$ & $0.192 b$ & $0.369 \mathrm{~b}$ & $0.817 \mathrm{c}$ & $1.967 \mathrm{bc}$ & $1.289 \mathrm{~b}$ \\
\hline Soaking in CSA for $1 \mathrm{~h}$. & $0.740 \mathrm{~b}$ & $0.195 b$ & $0.377 \mathrm{~b}$ & $0.787 \mathrm{~cd}$ & $2.097 \mathrm{~b}$ & $1.213 \mathrm{bc}$ \\
\hline Soaking in CSA for $\mathbf{2} \mathrm{h}$. & $0.736 \mathrm{~b}$ & $0.187 \mathrm{bc}$ & $0.365 \mathrm{~b}$ & $0.798 \mathrm{c}$ & $2.106 \mathrm{~b}$ & $1.200 \mathrm{bc}$ \\
\hline Soaking in CSA for $3 \mathrm{~h}$. & $0.749 \mathrm{~b}$ & $0.210 \mathrm{~b}$ & $0.381 b$ & $1.035 \mathrm{~b}$ & $2.138 b$ & $1.186 \mathrm{c}$ \\
\hline
\end{tabular}

- T.W. = Tap water, H.W. = Hot water and CSA = Concentrated sulfuric acid .

- Means within a column having the same letters are not significantly different according to Duncan's New Multiple Range t-Test (DMRT) at $5 \%$ level.

In this regard, Kenneth (1979) indicated that the inhibitory effect of phenols due to modify the activity of IAA- oxidase and might therefore be acting on plant activities through changes endogenous auxins activity. On the same line, were those results postulated by Sanyang et al., (2008) on Acacia senegal, Azad et al. (2012) on Albizia procera and Rodrigues Junior et al. (2014) on Senna multijuga.

From the previous results, it can be advised to soak seeds of Mescal bean (Sophora secundiflora $)$ in hot water $\left(60-70{ }^{\circ} \mathrm{C}\right)$ for $48 \mathrm{~h}$. to obtain the best germination and seedling growth.

\section{REFERENCES}

Agba O. A., Asiegbu J. E. and Omaliko C. (2005). Effect of length of soaking in water at room temperature and hot water treatment on the germination of Mucuna flagellipes (Vogel ex Hook) seeds. Global J. Agric. Sci., 4 (1): 15-18.

Aliloo A. A. and Mustafavi S. H. (2014). Does physicochemical pre-treatments alleviate germination and dormancy of Sophora alopecuroides seeds? Azarian J.Agric., 1(1):6-10 .

A.O.A.C. Association of Official Agricultural Chemists (1990). "Official Methods of Analysis of the Association of Official Agricultural Chemists". $15^{\text {th }}$ Ed., Arlington, Virginia USA. 22201: 877-878.

Azad M. S., Biswas R. K. and Matin M. A. (2012). Seed germination of Albizia procera (Roxb.) Benth. in Bangladesh: a 
basis for seed source variation and presowing treatment effect. Fores. Stud. in China, 14 (2): 124-130.

Azad M. S., Paul N. K. and Matin M. A. (2010). Do pre-sowing treatment effect seed germination in Albizia richardiana and Lagerstroemia speciosa?. Front. Agric. in China, 4 (2): 181-184.

Brasil F.M. (1992). Ministério da Agricultura e da Reforma Agrária, Regras análisé de sementes. Brasilia: SNDA/DNDV/CLAV. pp 365.

Burrows G. E., Virgona J. M. and Heady R.D. (2009). Effect of boiling water, seed coat structure and provenance on the germination of Acacia melanoxylon seeds. Australian J. Botany, 57 (2): 139-147.

Delgado C. M., de Paula A. S., Santos M. And Paulilo M. T. S. (2015). Dormancybreaking requirements of Sophora tomentosa and Erythrina speciosa (Fabaceae) seeds. Rev. Biol. Trop., 63(1):285-294.

Dubois M., Smith F., Illes K. A., Hamilton J. K. and Rebers P. A. (1956). Colorimetric mehod for determination of sugars and related substances. Ann. Chem., 28 (3): 350-356.

Hartmann H. T. and Kester D. E. (1983). Plant Propagation: Principles and Practices. Prentice-Hall Inc., Inglewood Cliffs, N. J., USA. pp 662.

Hu X. W, Wang Y. R., Wu Y. P., Nan Z. B. and Baskin C. C. (2008). Role of the lens in physical dormancy in seeds of Sophora alpecuroides L. (Fabaceae) from north-west China . Aust. J. Agric. Res., 59 (6): 491497.

Huxley A., Griffiths M. and Levy M. (1992). The New Royal Hort. Society Dictionary of Gardening. The Stockton Press Ltd., New York, , N. Y., USA, vol. 4, pp 888.

Imani A. F., Sardoei A. S. and Shahdadneghad M. (2014). Effect of $\mathrm{H}_{2} \mathrm{SO}_{4}$ on seed germination and viability of Canna indica L. ornamental plant. Int'l. J. Adv. Bio. Biochem. Res., 2(1):223-229.

Jaganathan G. K. , Yule K. J. and Biddick M. (2018). Determination of the water gap and the germination ecology of Adenanthera pavonina (Fabaceae, Mimosoideae); the adaptive role of physical dormancy in mimetic seeds. A. B Plants, 10 (5):52-98.
Jaganathan G. K., Wu G. R., Han Y. Y. and Liu B. L. (2017). Role of the lens in controlling physical dormancy break and germination of Delonix regal . Plant Biol.(Stuttg).,19(1): 53-60.

Kak A., Devi L. C., Gupta V. and Singh N. (2007). Response of seed treatments on seed germination in wild Crotalaria species. Acta Hort., 752: 261-265.

Kenneth V. T. (1979). Physiology of Plant Growth and Development. B. Willkins TaTa, (ed.) McGraw-Hill Publishing Co. Ltd., New Delhi, India.

Mead R., Curnow R. N. and Harted A. M. (1993). Statistical Methods in Agriculture and Experimental Biology. $2^{\text {nd }}$ Ed., Chapman \& Hall Ltd., London, pp 335.

Moran R. (1982). Formula for determination of chlorophyllous pigment extracted with $\mathrm{N}$ $\mathrm{N}$-dimethyl formamide. Plant Physiol., 69: 1376-1381.

Mueller C. W. (2011). Growing Texas mountain laurel (Sophora secudiflora) and Coral bean (Erythrina herbacea) from seed. Texas AgriLife Extension Service, Texas A \& M. System, Texas,USA.

Odetola J. A. (1987). Studies on seed dormancy, viability and germination in ornamental palms. Principles, 31 (1): 24-30.

Rodrigues Junior R. A. G., Faria J. M. R., Vaz T. A. A., Nakamura A. T. and Jose A. C. (2014). Physical dormancy in Senna multijuga seeds: the role of seed structures in water uptake. Seed Science research, 24 (2): 147-157.

Ruter J. M. and Ingram D. L. (1991). Germination and morphology of Sophora secudiflora seeds following scarification. HortSci., 26 (3): 256-257.

Sanyang S. E., Kabura B. H. and Wenchi H. (2008). Effect of some seed pretreatments on emergence of Acacia senegal L. World J. Agric. Sci., 4 (2): 213-219.

SAS Institute. (2009). SAS/SAT User`s Guide Statistics.,Vers. 9, SAS. Institute Inc. Cary, N.C., USA.

Selvaraju P. and Selvaraj J. A. (1994). Effect of pre-sowing treatments on germination and vigour of seed in marigold (Tagetes erecta L.). Madras Agric. J., 81 (9): 469-497.

Shao L., Liu X. Q., Gituru R. W., Ruan R. and Chen L. Q. (2010). Effect of pre-treatment on breaking hard seed dormancy of Sophora davidii (Franch) SKeels, a native 
Chinese shrub with potential for vegetation restotation in degraded habitates. Seed Sci. and Tech., 38 (3): 792-796.

Steel R. G. D. and Torrie J. H. (1980). Principles and Procedures of Statistics. McGraw Hill Book Co., Inc., New York, USA. pp. 377400.
Wang Y. T. (1991). Enhanced germination of Sophora secudiflora seeds. Suptropical Plant Sci., 44: 37-39.

William M., Chichlilo P., Clifford P. A. and Reynolds M. (1965). Official Methods of Analysis of the Association of Official Agriculture Chemists, $10^{\text {th }}$ Ed., Washington D.C. USA. 20044: 52-55.

$$
\begin{aligned}
& \text { دراسات فسيولوجية على إنبات وتسميد نبات السوفورا } \\
& \text { 1. إنبات بذور السوفورا (Sophora secundiflora) صعبة الإنبات فئات النيات } \\
& \text { أحمد وهبه سبي } \\
& \text { قسم بحوث الزينة وتنسيق الحدائق ـ معهد بحوث البساتين ـ مركز البحوث الزر اعية ـ الجيزة ـ مصر }
\end{aligned}
$$

\section{ملخص}

تعاني بذور شجرة السوفورا (Sophora secundiflora) من سكون طبيعي بسبب الصلابة العالية لأغلفتها

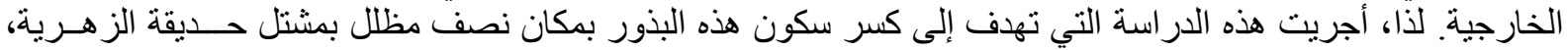

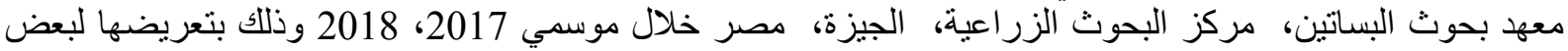

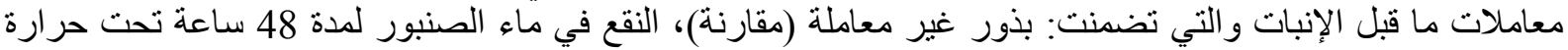

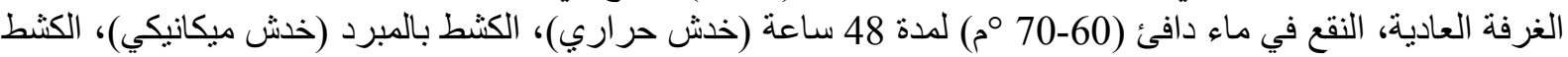

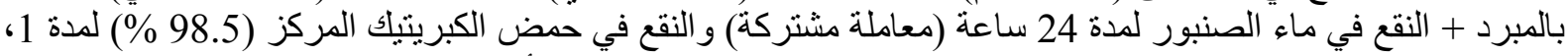

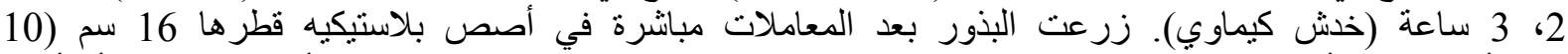

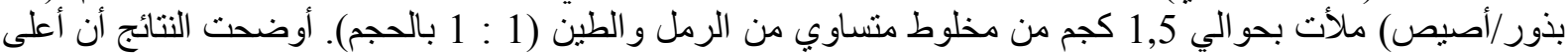

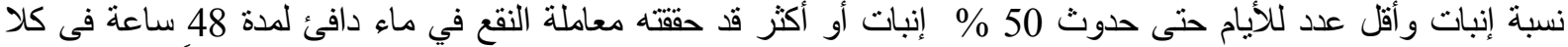

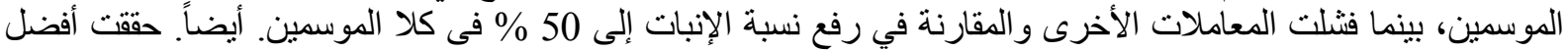

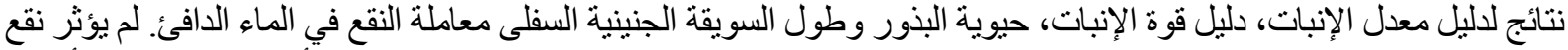

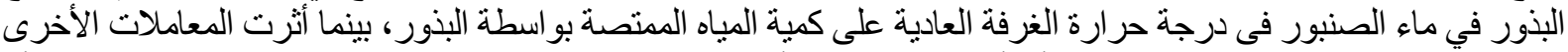

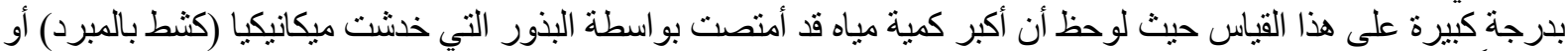

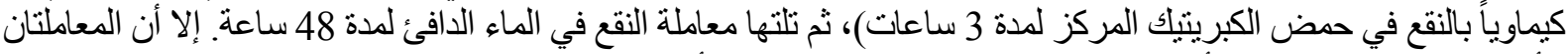

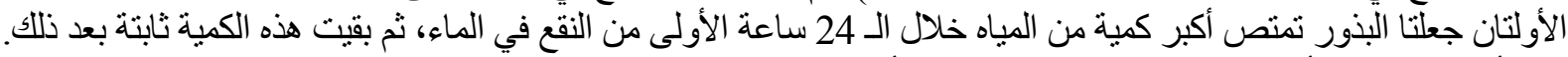

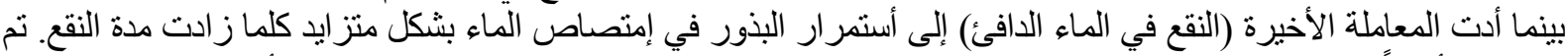

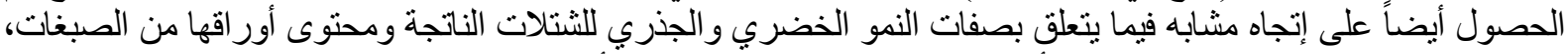

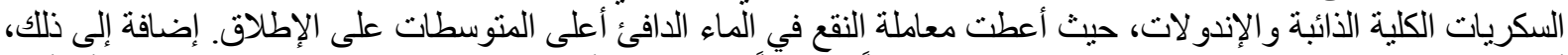

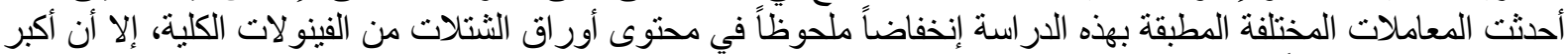

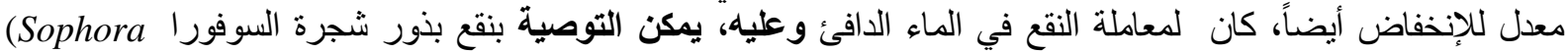
secundiflora) للشتلات الناتجة.

المجلة العلمية _ كلية الزراعة ـ جامعة القاهرة ـ المجلا (70) العدد الثالث (يوليو 2019):247- 255. 